\title{
Feeding biology and biochemical composition of the lessepsian migrant Octopus aegina (Cephalopoda: Octopodidae)
}

Inas H. Osman; Howaida R. Gabr; Salah G. El-Etreby and Saad Z. Mohammed

Marine Science Department, Faculty of Science, Suez Canal University, Ismailia, Egypt

\section{ABSTRACT}

The natural feeding of 609 Octopus aegina was studied in relation to the environmental seasonal variations in three populations in the Suez Canal, the Gulf of Suez and the Mediterranean Sea. Samples were collected seasonally from March 2009 till May 2010. Analysis of the stomach contents revealed that $O$. aegina attained the highest percentages of empty stomachs during spring for the three populations. The $(1 / 2)$ full stomachs was dominant in the collected samples $(32.97 \%)$. The study revealed that $34.43 \%, 32.83 \%$ and $32.10 \%$ of the examined stomachs were empty in the samples of Suez Canal, Gulf of Suez and Mediterranean, respectively. There was no definite seasonal food preference, and crustaceans were the most preferable food item followed by fishes. The biochemical composition of $O$. aegina revealed that females are higher than males in total protein content $(72.41 \%$ and $69.29 \%$ for immature and mature females respectively) and total lipid content $(38.4 \mathrm{~g} / 100 \mathrm{~g}$ dry weight and $33.2 \mathrm{~g} / 100 \mathrm{~g}$ dry weight for immature and mature females respectively). Amino acid analysis showed that $O$. aegina contains higher percentage of non essential amino acids (NEAA) than essential amino acids (EAA). Leucine, Lysine and Arginine had the highest percentage of EEA, while Asparagine, Glutamate and Glycine had the highest percentage of NEAA. EAA in males increased from $36.64 \%$ to $37.93 \%$ in immature and mature respectively, while in females it increased from $36.93 \%$ to $41.5 \%$ in immature and mature respectively. Fatty acid analysis showed that males O. aegina contain higher percentage content of fatty acid components (SFA and UFA) than females. The results also revealed that SFA tended to decrease by maturation in males and females. Palmitic (16:0) and Stearic (18:0) were the most abundant SFA. Mature males had the highest percentage content of PUFA.

Keywords: Octopus aegina, Lessepsian migration, feeding biology, Biochemical composition.

\section{INTRODUCTION}

Food and feeding habits are vital part of biological and taxonomical studies due to their role in the organism's growth, development and reproduction. All these biological processes depend on energy that enters the organism's body in the form of food (Wootton, 1992). Understanding of the natural diet of a species is imperative for the formation of its nutritional needs and of its relations with other organisms (Albertoni et al., 2003). In general, cephalopods prey on a variety of species, mainly crustaceans and molluscs, and to a lesser extent on other invertebrates or fish (Guerra and Nixon 1987). On the other hand, Cephalopods are thought to have rapid digestion rates, but estimates of duration of digestion have widely varied (Venkatesan, 2012).

The biochemical composition of cephalopods has been studied in a number of species inhabiting both coastal and oceanic waters and originating from tropical, temperate or polar environments (Moltschaniwskyj and Semmens, 2000). On the other hand, cephalopods have a vigorous protein and amino acid metabolism, and, therefore, a high amino acid requirement exists to maintain optimal growth and to 
supply energy (Lee, 1994). The direct use of protein as an energy reserve may account for the lack of major glycogen and lipid reserves in cephalopod tissues (O'Dor et al. 1983).

Octopus aegina Gray, 1849 is a Lessepsian migrant species (Galil, 2007). It is a benthic species taken on sandy to muddy see floor in the tropical and temperate latitudes (Roper et al., 1984). It is trawled out of the coastal waters of Western Pacific, Indian Ocean, Red Sea, Japan to Mozambique, South China Sea (Voss and Williamson, 1971) and Gulf of Thailand (Norman and Lu, 2000) within a depth range 30-120 m. (Roper et al., 1984). However, a population of O. aegina, whose original distribution is the Indian Ocean and the Red Sea, was encountered and recorded for the first time in the Suez Canal in the 2007s (personal observation) when fishermen were considered octopus as a by-product of the catch. Now in Egypt, O. aegina is caught throughout most of the year by fishermen, mainly for fishing purposes and for human food. Hence, the importance of this study as the first detailed study on food and feeding habits of this species in Egypt.

This study aims to elucidate the feeding biology of Octopus aegina, including feeding intensity and food composition in three sites; the Suez Canal, the Gulf of Suez and the Mediterranean Sea. In addition, the biochemical composition of O. aegina in the Suez Canal is determined and compared between sexes and in different maturity stages. Biochemical composition includes determination of total carbohydrates, total lipids, total cholesterol and moisture; also, Fatty acids and Amino acids profiles were determined.

\section{MATERIALS AND METHODS}

\section{1- Study area and sampling}

Octopus aegina were collected from three populations along the coast of Deversoir on Great Bitter lake at the Suez Canal, the coast of Suez on the Gulf of Suez and the coast of Damietta on the Mediterranean Sea (Fig. 1). The samples were collected seasonally from March 2009 till May 2010. The samples were caught by local fishermen using artisanal beach seine and gill net in Suez Canal and industrial trawling nets in the Gulf of Suez and the Mediterranean.

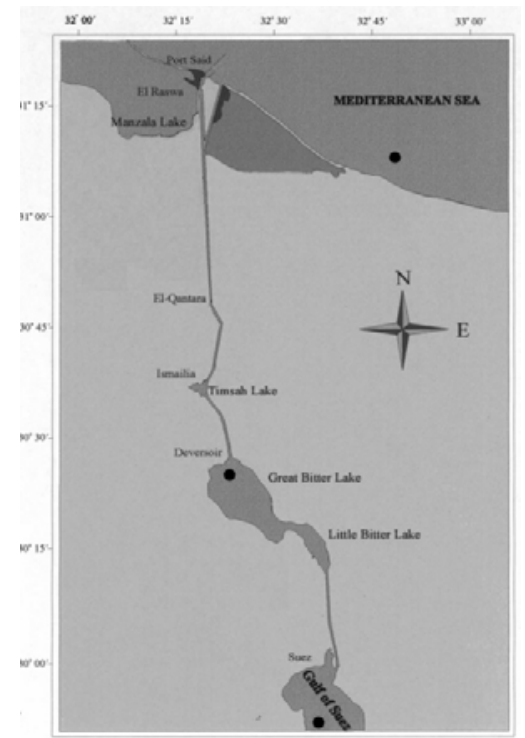

Fig. 1: Map showing the sampling sites in the Suez Canal, the Gulf of Suez and the Mediterranean Sea. 
In total, 609 individuals were analyzed, 409 collected from the Suez Canal, 152 from the Gulf of Suez and 148 from the Mediterranean.

\section{2- Feeding biology}

Stomachs of all specimens were removed and freshly weighed to the nearest gram. Empty stomachs were discarded and the rest were prepared for observation by cutting; the food content of each stomach was removed on a Petri dish and diluted with tap water to be ready for identification. Identification of the food contents was done using a stereomicroscope. The food items were identified to the lowest possible taxonomic level. The feeding intensity was determined visually by the degree of the fullness of the stomach, it was scaled as $0,1 / 4,1 / 2,3 / 4$ and Full feeding intensity. The stomach contents and food composition were broadly classified into five categories: Fish remains, Crustacean remains, Sand remains, unidentified remains and Digested matter.

Contribution of different food items to the diet was determined and calculated by frequency of occurrence $(\% \mathrm{~F})$, where $(\mathrm{x})$ is the number of every food item and (n) is the total number of stomachs containing food (Hyslop, 1980).

$$
\mathrm{F}=\frac{x \times 100}{n}
$$

\section{3- Biochemical composition}

For each individual, dorsal mantle length (DML, mm), total weight (Tw, g), gonad weight $(\mathrm{Gw}, \mathrm{g})$ and digestive gland weight $(\mathrm{Dg} \mathrm{w}, \mathrm{g})$ were recorded. Sex and maturity stages were determined for each individual. The biochemical analysis was performed in triplicate in these tissues.

The moisture content was determined according to A.O.A.C. (2000). Total protein was determined colorimetrically according to Josephson and Gyllensward (1957). Total carbohydrates were determined colorimetrically according to Duboies et al., (1956).Total cholesterol was determined colorimetrically according to Allain et al., (1974).Total lipids were calculated using Soxtherm, Gerhadt, laboratory instrument. Amino acids were determined using the Automatic Amino Acid Analyzer, AAA 400, INGOS Ltd., acid hydrolysis was carried out according to the method of Block et al., (1958). Fatty acids profile was determined by using Gas Lipid Chromatography according to Farag et al., (1986).

\section{RESULTS}

\section{Feeding Biology}

Samples in size range of 30 to $95 \mathrm{~mm}$ (DML) were used.

\section{Empty stomachs and feeding intensity}

In the Suez Canal and for the combined sexes, $34.43 \%$ of the examined stomachs were empty. In males $35.78 \%$ of males' stomachs were empty and ranged between $13.14 \%$ in autumn sample and $34.55 \%$ in spring sample. In females, 32.52 $\%$ of females' examined stomachs were empty. The empty stomachs fluctuated between $8.33 \%$ in summer sample and $18.18 \%$ in spring (Figs. 2 \& 3). Regarding feeding intensity, males Octopus aegina in the Suez Canal seemed to feed in a steady rate during different seasons. It attained the highest feeding intensity with a half and quarter stomach fullness during summer and autumn $(22.62 \%$ and $22.63 \%$ respectively). Only $1.65 \%$ of the examined stomachs of males was full and appeared only in winter (Fig. 2). In females, again the half stomach fullness was dominated in summer as the highest seasonal feeding intensity percentage $(41.67 \%)$. Active 
feeding was observed during autumn and winter where varied stomach fullness encountered (Fig. 3). Spring and summer had the least variation in feeding intensity.

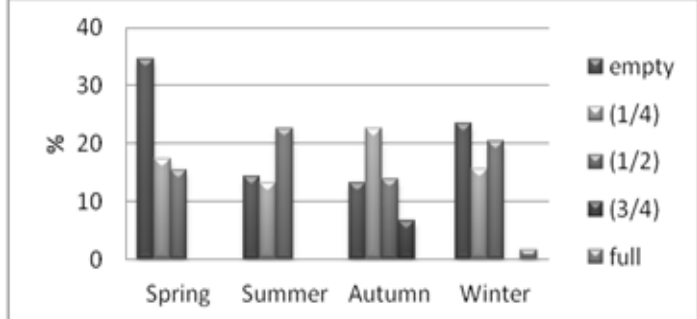

Fig. 2: Percentage of empty stomachs and stomach fullness for males Octopus aegina in the Suez Canal.

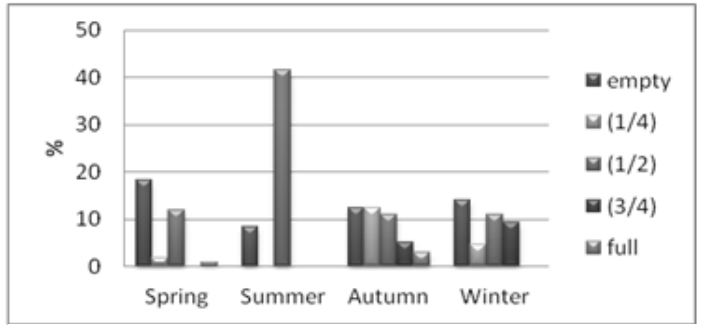

Fig. 3. Percentage of empty stomachs and stomach fullness for females Octopus aegina in the Suez Canal.

In the Gulf of Suez, $32.83 \%$ of the examined stomachs of males and females were empty. In males, $40.22 \%$ of males' stomachs were empty. The seasonal percentage of empty male stomachs ranged between $0 \%$ in summer and $46 \%$ in spring. In females, $26.42 \%$ of females' stomachs were empty. The seasonal percentage of empty female stomachs fluctuated between $0 \%$ in summer and $30 \%$ in spring (Figs. $4 \& 5$ ). In the Gulf of Suez and in males, quarter full stomach was dominated during the sampling period $(\approx 50.17 \%)$ followed by half full stomach $(\approx$ $48.50 \%)$. Spring was the lowest feeding active season. Although the moderate feeding activity during the following seasons, summer was considered as the highest feeding season; in which the highest quarter and half full stomach were encountered (26\% and $20 \%$ respectively) (Fig. 4). Females in the Gulf of Suez and as generally seemed to be more active in feeding than males; half full stomach was the highest feeding intensity percentage in all seasons with highest percentage in winter $(29.17$ $\%)$. Spring had the lowest feeding activity and followed by the highest feeding active season, summer; in which there were different degree of stomach fullness intensity and the highest full stomach was encountered (10\%) (Fig. 5).

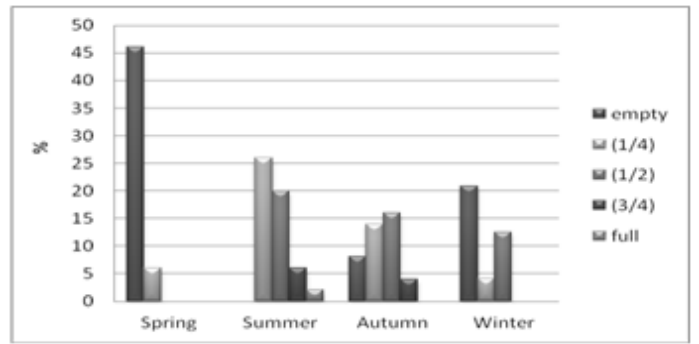

Fig. 4: Percentage of empty stomachs and stomach fullness for males Octopus aegina in the Gulf of Suez.

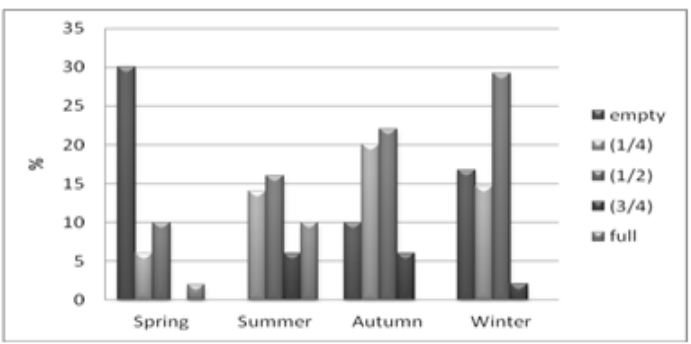

Fig. 5: Percentage of empty stomachs and stomach fullness for females Octopus aegina in the Gulf of Suez.

In the Mediterranean Sea and for the combined sexes, $32.10 \%$ of the stomachs were empty. $26.74 \%$ of males' stomachs were empty with seasonal fluctuation between $2.50 \%$ in summer and $29.17 \%$ in winter. In females, empty stomachs percentage were $39.02 \%$ with seasonal fluctuation from $10 \%$ in summer to $35.42 \%$ in winter (Figs. 6\&7). In the Mediterranean Sea, half and quarter full stomachs were dominated through the sampling period. In males and for the whole sampling period, half full stomach was the highest feeding intensity percentage $(19.57 \%)$ followed by the quarter full stomachs $(18.48 \%)$. Summer and autumn were the most active 
feeding intensity seasons. In summer, $40 \%$ of the examined male stomachs were quarter full, while in autumn, $24 \%$ of the examined stomachs were quarter and half full. Winter had the lowest percentage of feeding intensity (Fig. 6). In females, spring and summer were more active in feeding intensity. Quarter full stomach was the highest in summer $(22.50 \%)$ while full stomachs reached its highest percentage in spring $(8.70 \%)$ (Fig.7).

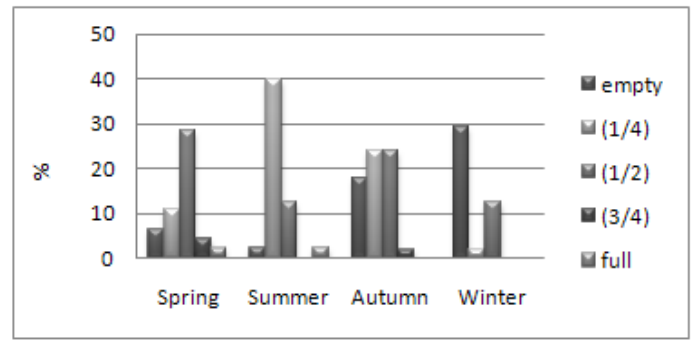

Fig. 6: Percentage of empty stomachs and stomach fullness for males Octopus aegina in the Mediterranean Sea.

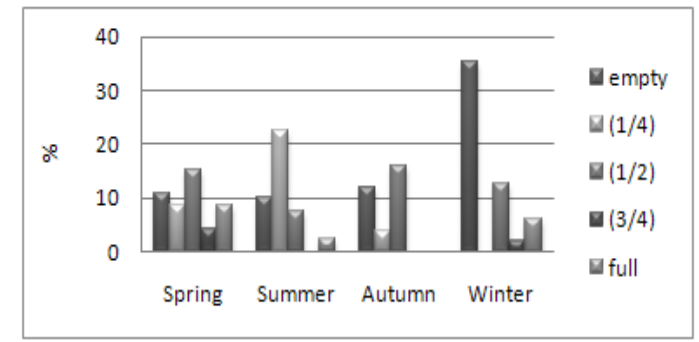

Fig. 7: Percentage of empty stomachs and stomach fullness for females Octopus aegina in the Mediterranean Sea.

\section{Food composition}

In the Suez Canal and in males, crustaceans formed $31.27 \%$ of the octopus diet. Maximum percentage occurrence of crustaceans as a food item was in spring (42.31 $\%$ ) and winter (40\%) while it was the lowest in summer (10.77\%). Fishes comprised $18.15 \%$ of the diet with a range between $6.15 \%$ in summer to $30 \%$ in winter. In females, crustaceans formed $23.49 \%$ followed by fishes $8.11 \%$ of the octopus diet. Autumn and winter were the seasons with the highest percentage occurrence of crustaceans (30.39\% and $37.50 \%$ respectively) and fishes $(12.75 \%$ and $10 \%$ respectively) (Fig. 8). In the Gulf of Suez and according to Fig. (9), in males, autumn is considered as the feeding season where all food items were encountered with the highest percentage occurrence of crustaceans (29.29\%). Fig. (9) shows that females continued to feed from summer to winter where the all food items were recorded.

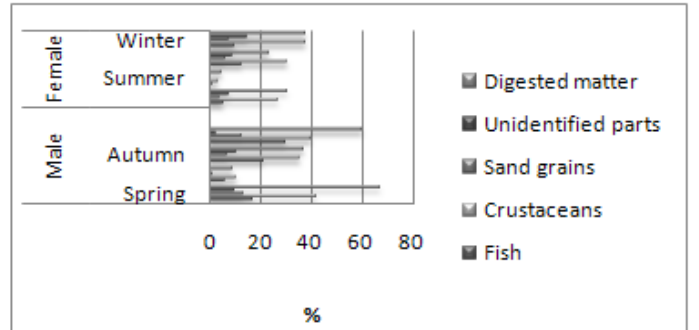

Fig. 8: Seasonal percentage occurrence of food items in male and females Octopus aegina in the Suez Canal.

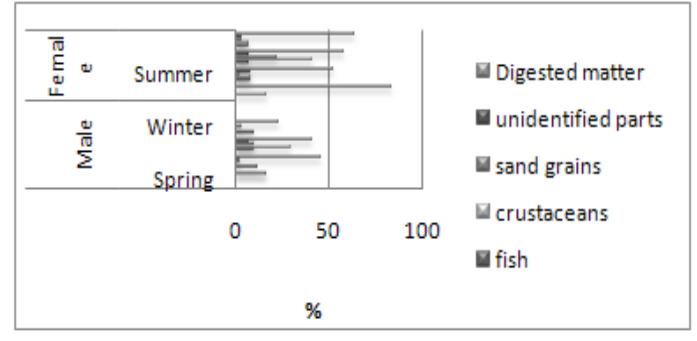

Fig. 9: Seasonal percentage occurrence of food items in male and females Octopus aegina in the Gulf of Suez.

Crustaceans were the most abundant food item in the female diet with the highest occurrence percentage in autumn (41.46\%) and the lowest in winter $(6.67 \%)$. Fish appeared in the females' diet in a moderately low percentage, the highest percentage occurrence of fishes was in summer $(8 \%)$.

In the Mediterranean Sea and in males, all food items attained its highest percentage occurrence during autumn. Crustaceans composed $51.43 \%$ of the diet as the highest percentage occurrence. Low feeding activity was in winter due to poor representation of different food items and the lowest percentage occurrence of the digested matter (41.18 \%) (Fig. 10). Similarly, females' feeding season was in autumn 
and crustaceans were the most occurred food items with the highest percentage occurrence of $42.86 \%$. The lowest feeding activity was in spring (Fig. 10).

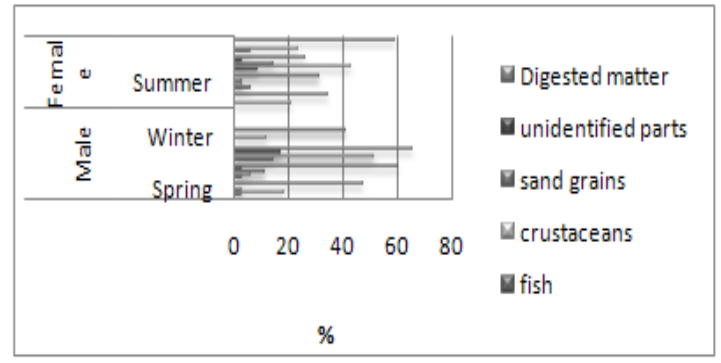

Fig. 10: Seasonal percentage occurrence of food items in male and females Octopus aegina in the Mediterranean Sea.

\section{Biochemical composition}

Octopus samples used in the analysis were ranged between $206 \pm 20.51$ and $288.5 \pm 7.78 \mathrm{~mm}$ DML, while its total weights were ranged between $35.78 \pm 1.94$ and $75.3 \pm 6.36 \mathrm{~g}$.

\section{Proximate composition}

The proximate composition of the investigated specimens (Table 1) showed high percentage of total protein with maximum value $(72.41 \%)$ in immature females and minimum value $(64.53 \%)$ in immature males. On the other hand, the table showed low percentage of total lipids, ranged between $28.5 \%$ in mature males and females and $38.4 \%$ in immature females.

Table 1: Mean values of proximate composition of the investigated Octopus aegina

\begin{tabular}{|c|c|c|c|c|c|}
\hline & & $\begin{array}{c}\text { Moisture } \\
(\mathbf{\%})\end{array}$ & $\begin{array}{c}\text { Total Protein } \\
(\mathbf{\%})\end{array}$ & $\begin{array}{c}\text { Total Carbohydrates } \\
(\mathbf{\%})\end{array}$ & $\begin{array}{c}\text { Total Lipids } \\
(\%)\end{array}$ \\
\hline Male & Immature & 82.28 & 64.53 & 24.28 & 29.5 \\
\hline & Mature & 81.70 & 68.20 & 29.53 & 28.5 \\
\hline Female & Immature & 79.73 & 72.41 & 29.97 & 38.4 \\
\hline & Mature & 79.43 & 69.29 & 29.24 & 28.5 \\
\hline
\end{tabular}

\section{Amino acids}

According to Table (2), Octopus aegina contains higher percentage of non essential amino acids (NEAA) than essential amino acids (EAA) for the two studied developmental stages. Percentages of EAA tended to increase as octopus get mature for both sexes.

In males, percentages of EAA increased from $36.64 \%$ in immature males to $37.93 \%$ in mature males; while in females it increased from $38.93 \%$ to 41.5 in immature and mature females respectively. The major EAA were Leucine, lysine and Arginine. Percentages of NEAA varied between the lowest percentage of $46.74 \%$ in mature females and the highest percentage of $51.38 \%$ in immature males. The major NEAA were Glycine and Glutamate. 
Table 2: Relative percentages of essential (EAA) and non essential amino acids (NEAA) in immature and mature males and females of Octopus aegina

\begin{tabular}{|l|c|c|c|c|}
\hline \multirow{2}{*}{\multicolumn{1}{c|}{ EAA }} & \multicolumn{4}{|c|}{ Relative percentage (\%) } \\
\cline { 2 - 5 } & \multicolumn{2}{|c|}{ Male } & \multicolumn{2}{c|}{ Female } \\
\hline Threonine (Thr) & Immature & Mature & Immature & Mature \\
\hline Valine (Val) & 4.25 & 3.61 & 3.73 & 3.93 \\
\hline Methionine (Met) & 3.94 & 4.18 & 4.51 & 4.62 \\
\hline Isoleucine (Ile) & 2.39 & 2.24 & 2.50 & 2.36 \\
\hline Leucine (Leu) & 3.79 & 3.90 & 3.77 & 3.84 \\
\hline Phenylalanine (Phe) & 7.84 & 8.14 & 8.33 & 9.34 \\
\hline Histidine (His) & 2.03 & 2.07 & 1.77 & 2.24 \\
\hline Lysine (Lys) & 1.56 & 1.52 & 1.4 & 1.63 \\
\hline Arginine (Arg) & 5.30 & 7.07 & 7.46 & 7.92 \\
\hline Total & 5.54 & 5.20 & 5.46 & 5.62 \\
\hline NEAA & 36.64 & 37.93 & 38.93 & 41.5 \\
\hline Asparagine (Asp) & \multicolumn{4}{|c|}{} \\
\hline Serine (Ser) & 10.13 & 10.39 & 10.11 & 10.36 \\
\hline Glutamate (Glu) & 4.62 & 3.34 & 4.13 & 4.14 \\
\hline Glycine (Gly) & 12.22 & 11.40 & 12.06 & 11.18 \\
\hline Alanine (Ala) & 13.08 & 12.63 & 11.56 & 10.09 \\
\hline Tyrosine (Tyr) & 9.48 & 8.80 & 9.07 & 8.60 \\
\hline Total & 1.85 & 2.09 & 2.31 & 2.37 \\
\hline & 51.38 & 48.65 & 49.24 & 46.74 \\
\hline
\end{tabular}

\section{Fatty acids}

Table (3) shows the relative percentage of Saturated Fatty Acids (SFA) and Unsaturated Fatty Acids (UFA) of Octopus aegina muscles. Males contained higher percentage of fatty acids components (SFA and UFA). In immature males, SFA were the highest (52.52\%) and when reach mature stage, UFA was being higher (49.56\%). Mature males were the highest in the relative percentage of polyunsaturated fatty acids (PUFA), docosapentaenoic $\left(\mathrm{C}_{22}: 5, \mathrm{n}-3\right)$, docosahexaenoic acid $\left(\mathrm{C}_{22}: 6, \mathrm{n}-3\right)$ and Eicosapentaenoic $\left(\mathrm{C}_{20}: 5, \mathrm{n}-3\right)$.

Table 3: Fatty acids components in the muscles of males and females at immature and mature developmental stage of Octopus aegina.

\begin{tabular}{|c|c|c|c|c|c|}
\hline & Name of components & \multicolumn{3}{|c|}{ Relative percentage (as area \%) } \\
\hline & & \multicolumn{2}{|c|}{ Male } & \multicolumn{2}{c|}{ Female } \\
\hline & & Immature & Mature & Immature & Mature \\
\hline \multirow{4}{*}{ SFA } & Lauric (12:0) & 5.342 & 1.494 & 4.409 & 1.023 \\
\cline { 2 - 6 } & Myristic $(14: 0)$ & 2.330 & 3.457 & 7.881 & 3.141 \\
\cline { 2 - 6 } & Palmitic (16:0) & 28.231 & 21.030 & 26.392 & 12.182 \\
\cline { 2 - 6 } & Margaric (17:0) & 2.547 & 3.087 & 2.440 & 1.565 \\
\cline { 2 - 6 } & Stearic (18:0) & 14.059 & 16.197 & 13.296 & 9.467 \\
\hline Total \% & & 52.509 & 45.265 & 54.418 & 27.378 \\
\hline \multirow{5}{*}{ UFA } & Palmitelaidic $(16: 1)$ & 0.740 & 0.505 & 0.681 & 0.813 \\
\cline { 2 - 6 } & Oleic $(18: 1)$ & 9.061 & 5.071 & 5.914 & 2.089 \\
\cline { 2 - 6 } & Linoleic $(18: 2)$ & 0.971 & 0.452 & 0.347 & 0.558 \\
\cline { 2 - 6 } & Lionlenic $(18: 3)$ & 4.924 & 6.603 & 14.014 & 5.747 \\
\cline { 2 - 6 } & Arachidonic $(20: 4)$ & $* *$ & 1.302 & 0.517 & 0.654 \\
\cline { 2 - 6 } & Eicosapentaenoic $\left(\mathrm{C}_{20}: 5, \mathrm{n}-3\right)$ & 9.157 & 12.436 & 6.409 & 5.217 \\
\cline { 2 - 6 } & Docosapentaenoic $\left(\mathrm{C}_{22}: 5, \mathrm{n}-3\right)$ & 5.899 & 7.912 & 6.278 & 6.226 \\
\hline Total \% & Docosahexaenoic $\left(\mathrm{C}_{22}: 6, \mathrm{n}-3\right)$ & 10.139 & 15.275 & 5.612 & 6.215 \\
\hline
\end{tabular}

$(* *):$ not detected 
Females showed a pronounced decrease in the fatty acids percentage as get mature. When females are immature, muscles' content of SFA was the highest (54.42 $\%$ ); and when being mature, the percentage content of SFA and UFA decreased and was nearly equal $(27.38 \%$ and $27.52 \%$ respectively). Palmitic (16:0) and Stearic (18:0) fatty acids had the highest percentage for immature and mature males and females Octopus aegina.

\section{DISCUSSION}

Empty stomachs were the highest in the samples of the Suez Canal followed by similar percentages in the Gulf of Suez and the Mediterranean samples. In the three studied sites, males had more percentages of empty stomachs than females. The present results agree with the results of many authors who recorded high percentage of empty stomachs in cephalopods (Pierce et al, 1994; Riad, 2000).

The high percentage of empty stomachs could be attributed to the high digestion rate of cephalopods or to the lack in available food supply (Venkatesan, 2012).The higher percentage of empty stomach of males than those of females in the present study may be due to the females need/store more energy for gamete maturation. This may consistent with the results of Garcia and Gimenez (2002). In their study on the effect of diet on ongrowing Octopus vulgaris, sex did not have any influence on the octopus growth rate but showed influence on feeding rate which was higher in females.

In the present study, the higher percentage of empty stomachs of Octopus aegina samples were in the spring for the Suez Canal and the Gulf of Suez samples and in winter for the Mediterranean samples. Spring in the present study is suggested to be the spawning season for O. aegina (Osman, 2014). Riad et al., (1997) reported that Octopus vulagris females stop feeding ten days before spawning and during the brooding periods, while Riad, (2000) reported that the highest percentage of empty stomachs were during the spawning periods of Octopus vulgaris, Eledone moschata and before spawning in O. macropus samples, while in the Mediterranean Sea, Octopus aegina attained its highest percentage of empty stomachs in winter. This may be related to the low temperature and it is effect on the feeding ability. According to Andre et al. (2009) the growth of Octopus pallidus was at its minimum rate during winter although the food availability. This is may reveal decreasing or stopping feeding during this cold season.

Regarding the seasonal feeding intensity, for the three studied sites, the present results revealed that half full stomachs was the dominant stomach fullness within the Octopus aegina samples and the summer was the highest feeding season for this species. Our results agree with many authors who reported increasing feeding activity during warm seasons. Katsanevakis et al. (2005) reported that Cephalopod respond to temperature increases by increasing their food intake.

Females Octopus aegina in the three studied sites follow more or less the same feeding activity pattern as males. The high feeding rate during autumn and winter may reflect the animal's readiness for spawning. These results come in accordance with many researchers who have well documented the relation between feeding intensity and the reproductive state of cephalopods (Cortez et al., 1995).

Percentage occurrence method and food composition analysis revealed that there is no definite seasonal food preference for Octopus aegina in the three studied sites and also revealed that presence of crustaceans as the main food item followed by fishes for both males and females. Octopuses are carnivorous predators and prefer to 
feed on a variety of live prey species (Fiorito and Gherardi, 1999). The present results agree with many researchers reported the same for other octopus species (Villanueva, 1993; Riad 2000).

It is worth to mention that the food organisms in the stomach were never observed as a whole; instead, they were crushed and broken into bites making their specific identity difficult or impossible to determine. On the other hand, octopuses are generally regarded as opportunistic predators (Iribarne et al., 1993). This can be seen by the wide variety of prey taken by Octopus aegina throughout the year.

Biochemical analyses of octopus tissues and diets could provide valuable information for nutritional requirements of octopus species and nutritional quality for human consumption purposes (Estefanell et al., 2011). In this study and regardless the sexual maturity stage, the biochemical composition of Octopus aegina in the present study revealed that females are higher than males in total protein content and total lipid content. Compared to fishes, cephalopods have $20 \%$ more protein, $80 \%$ less ash, $50-100 \%$ less lipid and 50-100\% less carbohydrate (Nurjanah et al., 2012).

In the present study, immature females tended to contain the highest protein content in the muscles and the digestive gland compared to mature females. High protein levels are important for the development of the gonads at a later maturity stage. Like all cephalopods, protein is an important nutrient both for growing and energetic metabolism (George-Zamora et al., 2011). Formation of gonads and preparation for laying fertilized eggs are the most energy-cost effective process in cephalopods. This may explain the increasing of protein level with maturation (Rosa et al., 2004a, b). In addition, protein is an important nutrient for tissue accretion and energy source (Rosas et al., 2007). Therefore; cephalopods require high amounts of protein and amino acids for optimum growth (George-Zamora et al., 2011). So, this may explain the high protein content within different octopus organs at different maturity stages to more than $50 \%$ in the present results.

Generally, Cephalopods' bodies contain low level of lipid (Battam et al., 2010). In the present results, analysis of total lipid content of Octopus aegina muscles revealed that in both males and females there was a trend of decreasing lipid content in the muscles with maturation. Females' muscles were higher in lipid content than males and were the highest when immature. This came in accordance with many authors (Navarro and Villanueva, 2003) in the study of O. vulgaris in wild and under culture condition. They stated that wild juveniles tend to lose lipids as they increase in weight. Semmens and Moltschaniwskyj (2000) also reported a decrease in the lipid content of adult individuals of the squid Sepioteuthis lessoniana compared with juveniles, and suggested that higher lipid content could act as energy storage for periods of low food availability. This may reflect the importance of the lipids as an energy source for gonad maturation and for subsequent embryo development

Amino acid analysis showed that Octopus aegina contains higher percentage of NEAA than EAA. Leucine, Lysine and Arginine had the highest percentage of EEA, while Asparagine, Glutamate and Glycine had the highest percentage of NEAA. It also resulted in that essential amino acids tended to slightly increase in the octopus muscles as being mature and attained the maximum percentage in mature females.

The present results of amino acids analysis agree with other cephalopod species in other areas in that Arginine, leucine and lysine were among the highest component of EAA (Nurjanah et al., 2012). The amino acids content could vary among organisms due to geographical differences, species, age and physiological condition (Capillas et al., 2002). The high level of these EEA in the tissue composition indicates that these amino acids could be limiting essential amino acids in their diets 
(Villanueva et al., 2004). Arginine is vigorously metabolized in cephalopods (Hochachka et al., 1983). During anaerobic work, Arginine phosphate is hydrolyzed leading to increased availability of the Arginine for condensation with glucosederived pyruvate to form octopine, the main anaerobic end product that accumulates in adult cephalopods during periods of exercise and stress (Storey et al., 1979). This may explain the high percentage of Arginine in immature male in the current study.

Fatty acid analysis showed that males Octopus aegina contain higher percentage content of fatty acid components (SFA and UFA) than females. The results also revealed that mature males had the highest percentage content of PUFA. Palmitic (16:0) and Stearic (18:0) were the most abundant fatty acids. This came in accordance with many cephalopod studies (Ozogul et al., 2008). The variation of fatty acid composition depends on species, food availability, age, geographical area, season and salinity (Ozyurt et al., 2006). Adult cephalopods are rich in long Polyunsaturated Fatty Acid (PUFA) (Thanonkaew and Visessanguan, 2006), in particular, adult males. According to our results and despite low lipid content of Octopus aegina, it may be considered as a good source of n-3 PUFA. These results correspond to those in previous studies (Ayas, 2012).

In conclusion, the results of this study indicate that Octopus aegina is generally regarded as opportunistic predators. Despite this opportunistic nature, the predominance of crustaceans in the diet of this species may reflect a greater energetic profitability of feeding on crustaceans, as compared with fish-based diet. On the other hand, O. aegina is a good source of protein with high content of EAA. The present study showed low lipids content of O. aegina. However, it is considered as a good source for omega-3 polyunsaturated fatty acid.

\section{REFERENCES}

AOAC (2000). Official methods of analysis of Association of Official Analytical Chemistry. 14th ed., Washington DC, USA.

Albertoni, E. F.; Palma-Silva, C. and Esteves, F. (2003). Natural diet of three species of shrimps in a tropical coastal Lagoon. Brazl. Arch. Biol. Tech., 46(3): 395 403.

Allain, C. C.; Poon, L. S.; Chan, C. S; Richmond, W. and Fu, P. C. (1974). Enzymatic determination of total serum cholesterol. Clin. Chem., 20: 470-475.

André, J.; Pecl, G. T.; Grist, E. P. M.; Semmens, J. M.; Haddon, M. and Leporati, S.C. (2009). Modeling size at age in wild immature female octopus: a bioenergetics approach. Mar. Ecol. Prog. Ser., 384: 159-174.

Ayas, D. (2012). Seasonal variations of fat and fatty acid composition in muscle tissues of Mediterranean octopuses. Iran. J. Fish. Sci., 11(4): 724-731.

Battam, H.; Richardson, M.; Watson, A. W. T. and Buttemer, W. A. (2010). Chemical composition and tissue energy density of the cuttlefish (Sepia apama) and its assimilation efficiency by Diomedea albatrosses. J. Comp. Phy., B 180: 12471255.

Block, R. J.; Durrum, E. L. and Zweig, G. (1958). A manual of paper chromatography and paper electrophoresis. Academic Press, New York.

Capillas, C. R.; Moral, A.; Morales, J. and Montero, P. (2002). Characterisation of non-protein nitrogen in the Cephalopods volador (Illex coindetii), pota (Todaropsis eblanae) and octopus (Eledone cirrhosa). Food Chem., 76(2): 165172. 
Cortez, J.; Castro, B. G. and Guerra, A. (1995). Reproductive and condition of female Octopus mimus (Mollusca: Cephalopoda). Mar. Biol., 123: 505-510.

Dubois, M.; Gilles, K. A.; Hamilton, J. K.; Rebers, P. A. and Smity, F. (1956). Colorimetric method for determination of sugars and related substances. Anal. Chem., 28: 350-356.

Estefanell, J.; Socorro, J.; Tuya, F.; Izquierdo, M. and Roo, J. (2011). Growth, protein retention and biochemical composition in Octopus vulgaris fed on different diets based on crustaceans and aquaculture by-products. J. Aqua., 322-323.

Farag, R. S., Ahmed, A. I.; Rashed, S. E.; Ewies, M. A. (1986). Unsaponifiable matter of six pollens collected by honey bees in Egypt. J. Agric. Res., 19 (4):52-58.

Fiorito, G. and Gherardi, F. (1999). Prey-handling behaviour of Octopus vulgaris (Mollusca, Cephalopoda) on bivalve preys. Behav.1 Proc., 46: 75-88.

Galil, B. S. (2007). Seeing Red: Alien species along the Mediterranean coast of Israel. Aqua. Inva., 2(4): 281-312.

García, G. B. and Giménez, A. F. (2002). Influence of diet on ongrowing and nutrient utilization in the common octopus (Octopus vulgaris). Aquacult., 211: 171-182.

George-Zamora, A.; Viana, M.; Rodríguez, S.; Espinoza, G. and Rosas, C. (2011). Amino acid mobilization and growth of juvenile Octopus maya (Mollusca: Cephalopoda) under inanition and re-feeding. Aquacult., 314: 215-220.

Guerra, A. and Nixon, M. (1987). Crab and mollusc shell drilling by Octopus vulgaris (Mollusca: Cephalopoda) in the Ria de Vigo (north-wet Spain). J. Zool. Lond., 211: 515-523.

Hochachka, P. W.; Mommsen, T. P.; Storey, J.; Storey, K. B.; Johansen, K. and French, C. J. (1983). The relationship between arginine and proline metabolism in cephalopods. Mar. Biol. Letters, 4: 1-21.

Hyslop, E. J. (1980). Stomach contents analysis: A review of methods and their applications. J. Fish. Biol., 17: 411-429.

Ibrahim, M. A.; Bebars, M. I.; Emam, W. M and Khatab, F. I. (1993). Age and Growth of Sepia savignyi from the Red Sea. J. Fac. Sci., U.A.E. University, 5(1): 20-35.

Josephson, B. and Gyllensward, C. (1957). The development of the protein fractions and of cholesterol concentration in the serum of normal infants and children. Scandinavian J. Clin. and Lab. Invest., 9(1): 29-38.

Katsanevakis, S.; Protopapas, N.; Miliou, H. and Verriopoulos, G. (2005). Effect of temperature on specific dynamic action in the common octopus, Octopus vulgaris (Cephalopoda). Mar. Biol., 146: 733-738.

Lee, P.G. (1994). Nutrition of cephalopods: Fuelling the system. Mar. Fresh. Behav. Phys., (25): 35-51.

Moltschaniwskuj, N. A. and Semmens, J. M. (2000). Limited use of stored energy reserves for reproduction by the tropical loliginid squid Photololigo sp. J. Zool. (London), 251: 307-313.

Navarro, J. C. and Villanueva, R. (2003). The fatty acid composition of Octopus vulgaris paralarvae reared with live and inert food: deviation from their natural fatty acid profile. Aquacult., 219: 613-631.

Norman, M. D. and Lu, C. (2000). Preliminary checklist of the cephalopods of the South China Sea. Raff. Bull. Zool., 85: 39-567.

Nurjanah, A. J.; Sulastri, R.; Nurzakiah, S. and Karmila, S. (2012). Proximate, Nutrient and Mineral Composition of Cuttlefish (Sepia recurvirostra). Adv. J. Food Sci. Tech., 4(4): 220-224. 
O'Dor, R. K.; Mangold, K.; Boucher-Rodoni, R.; Wells, M. J. and Wells, J. (1983). Nutrient absorption, storage and remobilization in Octopus vulgaris. Mar. Behav. Phys., 11: 239-258.

Inas, H. O. (2014). Biological and Morphological studies of a new migrant Octopus sp. (Cephalopoda: Octopodidae) to the Suez Canal. PhD Thesis, Suez Canal University, Egypt. 200 pp.

Ozogul, Y.; Duysak, O.; Ozogul, F.; Özkütük, A. S. and Türeli, C. (2008). Seasonal effects in the nutritional quality of the body structural tissue of cephalopods. Food Chem., 108: 847-852.

Ozyurt, G.; Duysak, O.; Akama, E. and Tureli, C. (2006). Seasonal change of fatty acids of cuttlefish Sepia officinalis L. (Mollusca: Cephalopoda) in the north eastern Mediterranean Sea. Food Chem., 95(3): 382-385.

Pierce, G. J.; Boyle, P. R.; Hastie, L. C. and Key, L. (1994). The life history of Loligo forbesi (Cephalopoda: Loliginidae) in Scottish waters. Fish. Res., 21: 17-41.

Riad, R. (2000). Biological and taxonomical studies on octopuses (Cephalopd octopod) from Egyptian Mediterranean waters. Ph.D thesis, Alex Univ., Egypt. $236 \mathrm{pp}$.

Riad, R.; Wadie, W. F. and Halim, Y. (1997). Development of Octopus vulgaris, Lamark from Egyptian Mediterranean waters. Bull. Nat. Inst. Ocean. Fish., A.R.E. 23: 389-411.

Roper, C. F.; Sweeney, M. J. and Nauen, C. E. (1984). FAO Species Catalogue. Vol. 3. Cephalopods of the world. An annotated and illustrated catalogue of species of interest to fisheries. FAO Fish. Synop. 125(3):277p. Rome: FAO.

Rosa, R.; Costa, P. R. and Nunes, M. L. (2004a). Effect of sexual maturation on the tissue biochemical composition of Octopus vulgaris and O. defilippi (Mollusca: Cephalopoda). Mar. Biol., 145: 563-574.

Rosa, R.; Costa, P. R.; Pereir, J. and Nunes, M. L. (2004b). Biochemical dynamics of spermatogenesis and oogenesis in Eledone cirrhosa and Eledone moschata (Cephalopoda: Octopoda). Comparative Biochemistry and Physiology - Part B: Biochem. Mol. Biol., 139: 299-310.

Rosas, C.; Cuzon, G.; Pascual, C.; Gaxiola, G.; Chay, D.; López, N; Maldonado, T. and Domínguez, P. M. (2007). Energy balance of Octopus maya fed crab or an artificial diet. Mar. Biol., 152: 371-381.

Semmens, J. M. and Moltschaniwskyj, N. A. (2000). An examination of variable growth in the loliginid squid Sepioteuthis lessoniana: a whole animal and reductionist approach. Mar. Ecol. Prog. Ser., 193: 135-141.

Storey, K. B.; Storey, J. M.; Johansen, K. and Hochachka, P. W. (1979). Octopine metabolism in the cuttlefish, Sepia officinalis. Effect of hypoxia and metabolite loads on the blood levels of octopine and related compounds. Canad. J. Zool., (57): 2331-2336.

Thanonkaew, A.; S. and Visessanguan, W. (2006). Chemical composition and thermal property of cuttlefish (Sepia pharaonis) muscle. J. Food Comp. Anal., 19(2-3): 127-133.

Venkatesan, V. (2012). Studies on fishery and Biology of the big fin squid, Sepioteuthis lessoniana (Lesson, 1830) from Mandapam waters. PhD thesis, Fac. Mar Sci., Annamalai Univ., Tamil Nadu, India, 205p.

Villanueva, R.; Riba, J.; Ruíz-Capillas, C.; González, A.V. and Baeta, M. (2004). Amino acid composition of early stages of cephalopods and effect of amino acid dietary treatments on Octopus vulgaris paralarvae. Aquacult., 242: 455-478. 
Villanueva, R. (1993). Diet and mandibular growth of Octopus magnificus (Cephalopoda). S. Afr. J. Mar. Sci., 13: 121-126.

Voss, O. L. and Willamson, Q. (1971). Cephalopoda of Hong'Kong. Govecot Dt Press, Hongkong: $138 \mathrm{p}$.

Wootton, T. (1992). Indirect effects, prey susceptibility, and habitat selection: impacts of birds on limpets and algae. Ecol., 73: 981-991.

\section{ARABIC SUMMRY}

بيولوجيا التظذية و التركيب البيوكيميائى للمهاجر الليسبسى أكتوبوس ايجينا (الر أسقديات : الأخطبوطية)

$$
\begin{aligned}
& \text { إيناس هلال عثمان - هويدا رشدى جبر -صلاح غريب الأتربى - سعد زكريا محمد }
\end{aligned}
$$

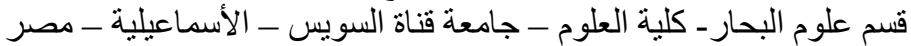

تم دراسة التغذية الطبيعية لعدد 9 ـ 7 من أكتوبوس /يجبنا وكذلك علاقتها بالتغيرات البيئية الموسمية

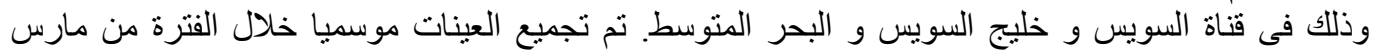

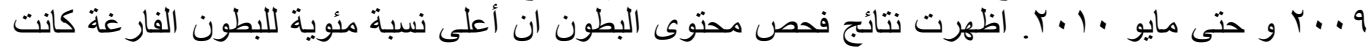

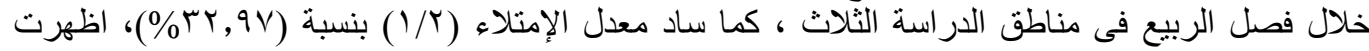

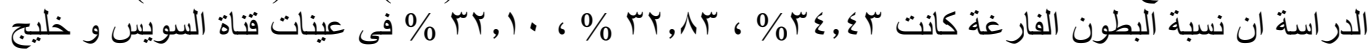

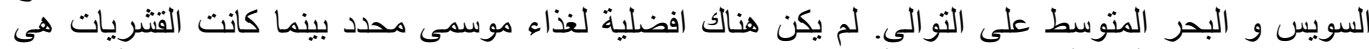

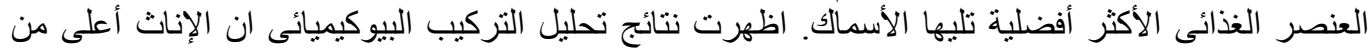

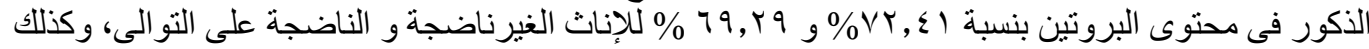

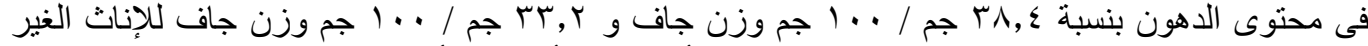

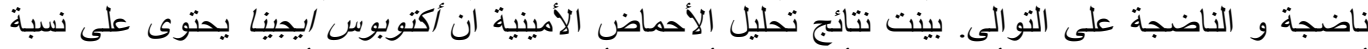

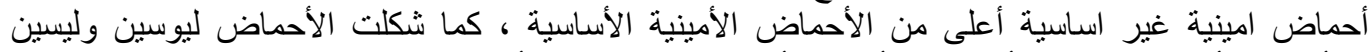

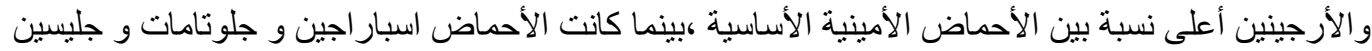

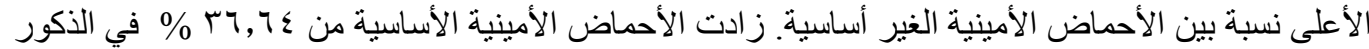

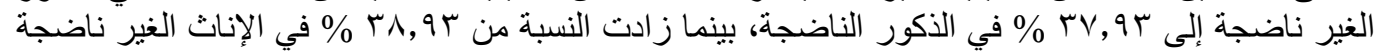

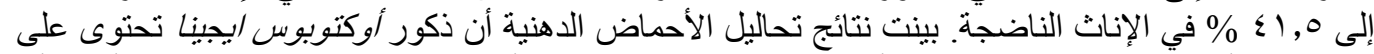

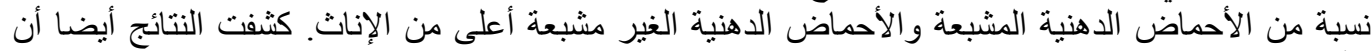

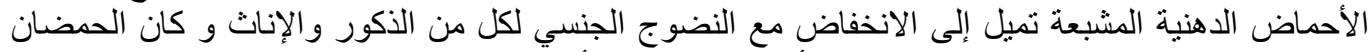

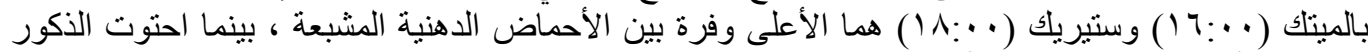
على نسبة أعلى من الإناث من الأحماض الدهنية الغير مشبعة المتعددة. 